\title{
PREVALENSI INFEKSI WHITE SPOT SYNDROME VIRUS (WSSV) PADA INDUK UDANG WINDU (Penaeus monodon) HASIL TANGKAPAN DARI ALAM
}

\author{
Hambali Supriyadi, Taukhid, Agus Sunarto, dan Isti Koesharyani
}

\begin{abstract}
ABSTRAK
Penelitian yang bertujuan untuk mengetahui prevalensi infeksi penyakit bercak putih (WSSV) pada induk udang windu hasil tangkapan dari alam telah dilakukan di Laboratotium Kesehatan Ikan, Pasar Minggu. Sampel induk udang windu dikoleksi dari penampung di beberapa lokasi (provinsi) yaitu Lampung, Banten, Jawa Barat, Jawa Tengah, Jawa Timar, dan Nusa Tenggara Barat. Penyiapan sampel serta prosedur pemeriksaan dilakukan dengan teknik polymerase chain reaction (PCR) dengan mengikuti prosedur standar. Hasil penelitian menunjukkan bahwa tidak semua induk udang hasil tangkapan dari alam terinfeksi oleh WSSV, ada kecenderungan bahwa prevalensi infeksi terkait dengan bulan-bulan tertentu atau musim. Prevalensi tertinggi didapat dari sampel yang berasal dari Pangandaran 2 hasil tangkapan bulan Januari (81\%) dan Pandeglang hasil tangkapan bulan Mei (50\%).
\end{abstract}

ABSTRACT: The prevalence of White Spot Syndrome Virus (WSSV) in black tiger shrimp brood stock captured from wild. By: Hambali Supriyadi, Taukhid, Agus Sunarto, and Isti Koesharyani

The aim of this research is to know the prevalence of WSSV in black tiger shrimp brood stock captured from the wild. The sample were collected from collector at different provinces i.e.: Lampung, Banten, West Java, Central Java, East Java, and West Nusa Tenggara. Sample preservation and diagnostic procedure have been done trough standard procedure of polymerase chain reaction $(P C R)$ and the data was analyzed descriptively. The results indicated that not all of shrimp brood stock captured from the wild infected by WSSV. The prevalence of WSSV seems to be related with season (January-May). The highest prevalence of WSSV was attained from sample collected from Pangandaran $2(80 \%)$ and Pandeglang (50\%).

KEYWORDS: prevalence, WSSV, black tiger shrimp, brood stock

\section{PENDAHULUAN}

Pembudidayaan udang penaeid di tambak sampai saat ini masih merupakan salah satu akuabisnis yang memberikan harapan bagi peningkatan kesejahteraan masyarakat. Hal ini disebabkan pasar komoditi udang masih terbuka, khususnya pasar ekspor. Namun akhirakhir ini, usaha budi daya udang terutama jenis udang windu secara umum sedang mengalami kelesuan akibat kegagalan produksi yang semakin sering terjadi. Salah satu kendala serius dan akan semakin kompleks sejalan dengan perkembangan budi daya udang penaeid adalah kegagalan akibat penyakit, baik yang bersifat infeksius maupun non infeksius. Hal ini sudah dirasakan sejak awal tahun 1990-an hingga saat ini. Kondisi tersebut, dapat dilihat dari keragaan produksi udang nasional yang mengalami penurunan yaitu dari sekitar 100,5 metrik ton pada tahun 1992 (Surtida, 2000) menjadi kurang dari 60.000 metrik ton pada tahun 1995 dan terus berfluktuasi hingga saat ini (Rukyani, 2000).
Kondisi memprihatinkan yang menimpa pembudidayaan udang windu di Indonesia sejak beberapa tahun terakhir ini merupakan akibat dari beberapa faktor yaitu antara lain: 1) disain tata letak yang tidak memenuhi persyaratan teknis, 2) infeksi patogen yang teknik penanggulangannya masih belum optimal, 3) luasan hamparan tambak yang kurang memperhitungkan kemampuan daerah penyangga, 4) penerapan padat tebar yang tidak sesuai dengan daya dukung lahan, 5) konversi lahan mangrove menjadi areal pertambakan yang dilakukan kurang bijaksana sehingga menghilangkan keberadaan jalur hijau, 6) pengelolaan budi daya udang yang kurang memperhatikan kaidah kelestarian lingkungan, dan 7) sumber cemaran baik internal maupun eksternal. Namun gangguan utama adalah seringnya timbul penyakit akibat infeksi White Spot Syndrome Virus (WSSV) yang dirasa sangat merugikan bagi pembudi daya udang. Penyakit bercak putih pertama 
kali dilaporkan tahun 1992 menyerang udang Penaeus japonicus di bagian Timur Laut Taiwan, kemudian sejak tahun 1993 menyebar dan selanjutnya menginfeksi udang $P$. monodon dan P. penicillatus (Chen, 1995 dalam Taslihan et al., 2004).

Selain menyerang udang windu dan udang putih, WSSV juga telah diketahui terdeteksi pada berbagai udang tangkapan laut, seperti Metapenaeus dopsoni, Pampenaeopsis stylifera, Solenocera indica, dan Squilla mantis, juga Macrobrachium rosenbergii yang hidup di kolam air tawar. Virus bercak putih juga ditemukan menginfeksi kepiting liar seperti Charybdis anulata, $C$. cruciata, Macrophthalmus sulcatus, dan Metapograpsus messar (Hosain et al., 2001).

Panti benih udang windu selama ini masih sepenuhnya mengandalkan pasokan induk dari hasil tangkapan di alam. Issue yang berkembang saat ini adalah adanya rumor yang menyatakan bahwa hampir $100 \%$ induk udang windu asal perairan Indonesia telah terinfeksi WSSV. Atas dasar keadaan inilah maka dilakukan penelitian inventarisasi prevalensi infeksi WSSV pada induk udang windu hasil tangkapan dari alam dari perairan sekitar Pulau Jawa, Bali, dan Lampung.

\section{BAHAN DAN METODE}

Lokasi pengambilan sampel ditentukan pada pusatpusat penangkapan induk udang windu dari alam yang meliputi: Lampung, Banten, Jawa Barat, Jawa Tengah, Jawa Timur, Bali, dan NTB, dikoleksi dari penampung induk yang ada di daerah tersebut. Sampel yang diperoleh di lapangan sudah ditampung oleh penampungan yang lamanya bervariasi antara 1-3 malam. Penelitian dilakukan mulai bulan JanuariOktober 2004. Riset juga menghimpun informasi yang terkait dengan sistem manajemen penanganan induk udang yang diterapkan oleh masing-masing responden/pengumpul/penangkap juga dielaborasi melalui penyediaan kuesioner terstruktur. Data dan informasi yang diperoleh selanjutnya dianalisis dan dievaluasi secara deskriptif.

Pemeriksaan untuk mengetahui keragaan sampel dilakukan menurut metode yang dikembangkan oleh Lightner (1996) dan Graindorge \& Flegel (1999) yang meliputi pemeriksaan umum secara visual di lapangan seperti gejala klinis, kelengkapan organ tubuh, ukuran induk udang (panjang total dan bobot), dan pemeriksaan laboratorium untuk sampel yang diduga terinfeksi patogen target (WSSV).

Penyiapan sampel dan prosedur pemeriksaan untuk mendeteksi White Spot Syndrome Virus dilakukan menurut prosedur yang dikembangkan oleh Lightner (1996) sampel berupa kaki renang (pleopod) dan insang yang difiksasi dengan menggunakan alkohol $70 \%$ sedangkan penyiapan sampel serta prosedur analisis dengan teknik polymerase chain

Tabel 1. Prevalensi White Spot Syndrome Virus (WSSV) pada induk udang windu (Penaeus monodon) yang berasal dari Lampung, Banten, Jawa Barat, Jawa Tengah, Jawa Timur, dan Nusa Tenggara Barat

Table 1. The prevalence of White Spot Syndrome Virus (WSSV) of penaid shrimp broodstock collected from Lampung, Banten, West Java, Central Java, East Java, and West Nusa Tenggara Provinces

\begin{tabular}{|c|c|c|c|c|}
\hline $\begin{array}{c}\text { Asal sampel } \\
\text { Sampling locations }\end{array}$ & $\begin{array}{l}\text { Prevalensi WSSV } \\
\text { WSSV prevalence } \\
\text { (\%) }\end{array}$ & $\begin{array}{c}\text { Jumlah } \\
\text { sampel } \\
\text { No. sample }\end{array}$ & $\begin{array}{c}\text { Tanggal } \\
\text { sampling } \\
\text { Date }\end{array}$ & $\begin{array}{c}\text { Keterangan } \\
\text { Note }\end{array}$ \\
\hline Lampung & 0 & 8 ekor & $26 / 08 / 04$ & \\
\hline \multicolumn{5}{|l|}{ Banten: } \\
\hline Tangerang & 40 & 5 ekor & $11 / 5 / 04$ & ukuran $100--200 \mathrm{~g}$ \\
\hline Pandeglang (Labuan) & 50 & 6 ekor & $14 / 5 / 04$ & ukuran $100--200 \mathrm{~g}$ \\
\hline Serang & 20 & 5 ekor & $15 / 5 / 04$ & ukuran $100--200 \mathrm{~g}$ \\
\hline \multicolumn{5}{|l|}{ Jawa Barat: } \\
\hline Pangandaran 1 & 0 & 5 ekor & $21 / 6 / 04$ & Gejala insang merah \\
\hline Pangandaran 2 & 81 & 11 ekor & $04 / 1 / 04$ & Sampel dari BBAP \\
\hline Pangandaran 3 & 0 & 8 ekor & $25 / 8 / 04$ & Sampel Ditjen PB \\
\hline \multicolumn{5}{|l|}{ Jawa Tengah: } \\
\hline Cilacap & 0 & 10 ekor & $30 / 9 / 04$ & \\
\hline Jawa Timur & 0 & 6 ekor & $11 / 10 / 04$ & Insang merah \\
\hline NTB & 54 & 11 ekor & $11 / 1 / 04$ & \\
\hline
\end{tabular}


reaction (PCR) dilakukan menurut metode yang dikembangkan oleh Yuasa et al. (1998) yang dimulai dengan proses ekstraksi sampel dalam ependorf dengan menggunakan lisis bufer; kemudian diamplifikasi dengan metode IQ 2000 (Manual beberapa kit yang relevan dengan target patogen, misalnya WSSV Detection and Prevention System/ Farming Intellegene Tech. Corp) dan dielectrophoresis, kemudian didokumentasikan dengan menggunakan foto polaroid.

\section{HASIL DAN BAHASAN}

Hasil monitoring terhadap beberapa sampel induk yang diperoleh dari beberapa daerah ternyata panjang induk udang berkisar antara 18 sampai $26 \mathrm{~cm}$ dengan bobot tubuh antara $100-250 \mathrm{~g}$. Secara rinci data prevalensi jumlah serta tanggal pengambilan sampel dapat dilihat pada Tabel 1. Dari data tersebut diketahui bahwa variasi prevalensi infeksi WSSV terjadi pada sampel yang diperoleh dari beberapa tempat. Di beberapa daerah penangkapan ada yang menunjukkan prevalensi tinggi tapi ada juga yang tidak menunjukkan adanya infeksi WSSV. Permasalahan dalam penelitian ini adalah bahwa jumlah sampel yang diperoleh tidak sama antara satu lokasi sampling dengan lainnya. Hal ini karena sampel diperoleh dari pengumpul yang sangat tergantung pada hasil penangkapan dari alam.

Di Provinsi Lampung (Kalianda) merupakan sentra aktivitas penangkapan induk udang windu. Di wilayah tersebut terdapat sedikitnya 5 (lima) pengumpul induk udang windu hasil tangkapan dari perairan sekitarnya. Dari sejumlah sampel yang diperoleh ( 9 ekor) ternyata tidak terdapat infeksi WSSV. Sampel induk udang dari Provinsi Banten dikoleksi dari 3 Kabupaten yaitu Tangerang, Pandeglang, dan Serang.
Prevalensi infeksi WSSV pada udang windu dari Kabupaten Pandeglang yang diperoleh dari pengumpul di tempat pendaratan ikan (TPI) Sidamukti ternyata paling tinggi $(50 \%)$ di antara Kabupaten lain di provinsi tersebut (Gambar 1). Demikian juga pada sampel yang diperoleh dari Kabupaten Tangerang yang berasal dari pengumpul di tempat pendaratan ikan Cicatih ternyata banyak terinfeksi WSSV (40\%).

Dari sampel induk udang windu yang berasal dari Pangandaran 1 menunjukkan adanya gejala klinis insang merah (Gambar 2). Adanya gejala demikian menurut pengumpul biasanya udang akan mati setelah 3 hari dalam penampungan. Menurut Koesharyani et al. (2001), udang dengan gejala klinis demikian ada kaitannya dengan infeksi WSSV.

Namun dari hasil pemeriksaan yang dilakukan di Laboratorium Riset Kesehatan Ikan, Pasar Minggu ternyata udang dengan gejala demikian tidak menunjukkan adanya infeksi WSSV. Hal yang sama juga diperoleh dari sampel yang berasal dari Jawa Timur (Gambar 3) yang menunjukkan gejala klinis insang merah. Hasil pemeriksaan bakteriologis dari sampel dengan gejala klinis tersebut ternyata diperoleh bakteri Vibrio sp. Hal ini sesuai dengan pernyataan Goarant et al. (2000) bahwa udang yang menunjukkan gejala putih pada karapas ternyata tidak dapat dipergunakan sebagai indikator serangan virus, karena kemungkinan dapat juga disebabkan oleh bakteri. Demikian juga dengan gejala merah walaupun Koesharyani et al. (2001) mengatakan gejala tersebut mengindikasi adanya infeksi WSSV namun secara laboratories ternyata tidak terdeteksi adanya virus WSSV.

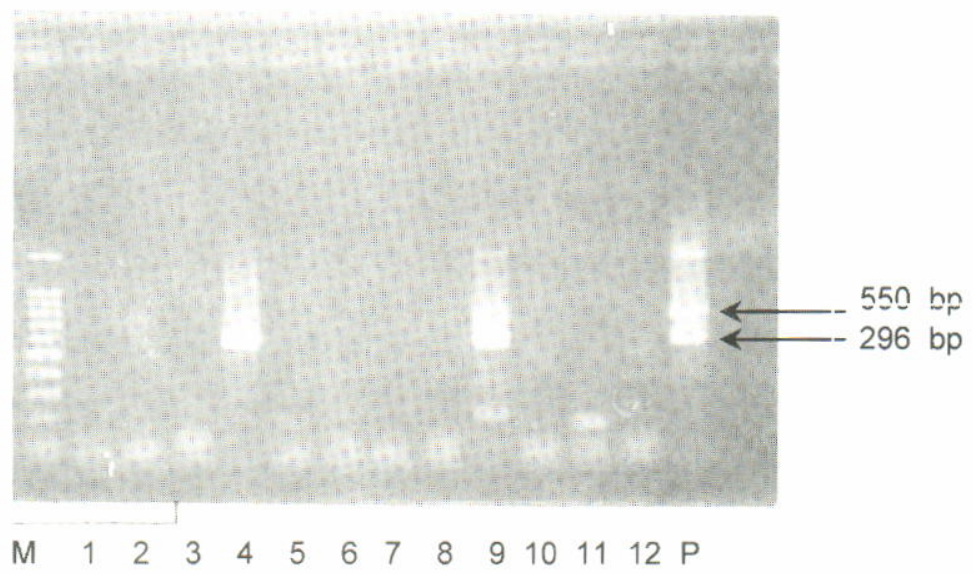

Gambar 1. Hasil analisis PCR sampel induk udang windu dari Serang (1-7) dan Pandeglang (8-12) $M=$ marker, $\mathrm{P}=$ kontrol positif

Figure 1. $\quad P C R$ analysis results of sample collected from Serang (1-7) and Pandeglang (8-12), $M=$ Marker, $P=$ positive control 


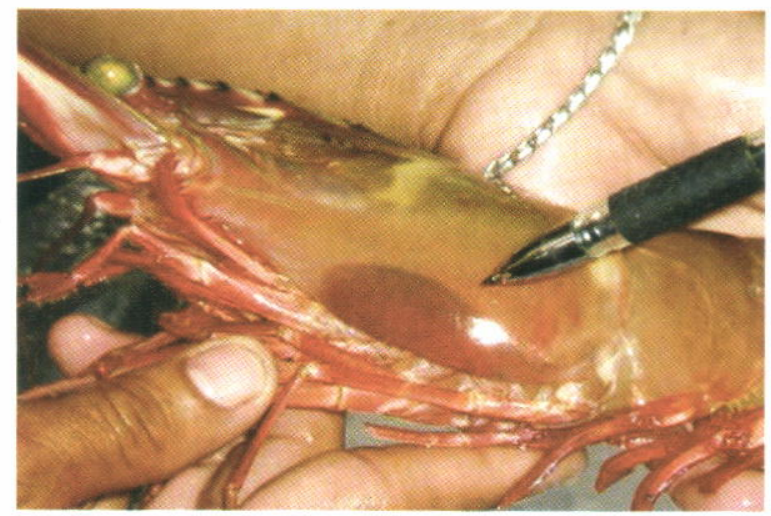

Gambar 2. Induk udang windu dari Pangandaran dengan gejala klinis insang merah Figure 2. Penaeid shimp broodstock collected from Pangandaran which indicated reddish gill

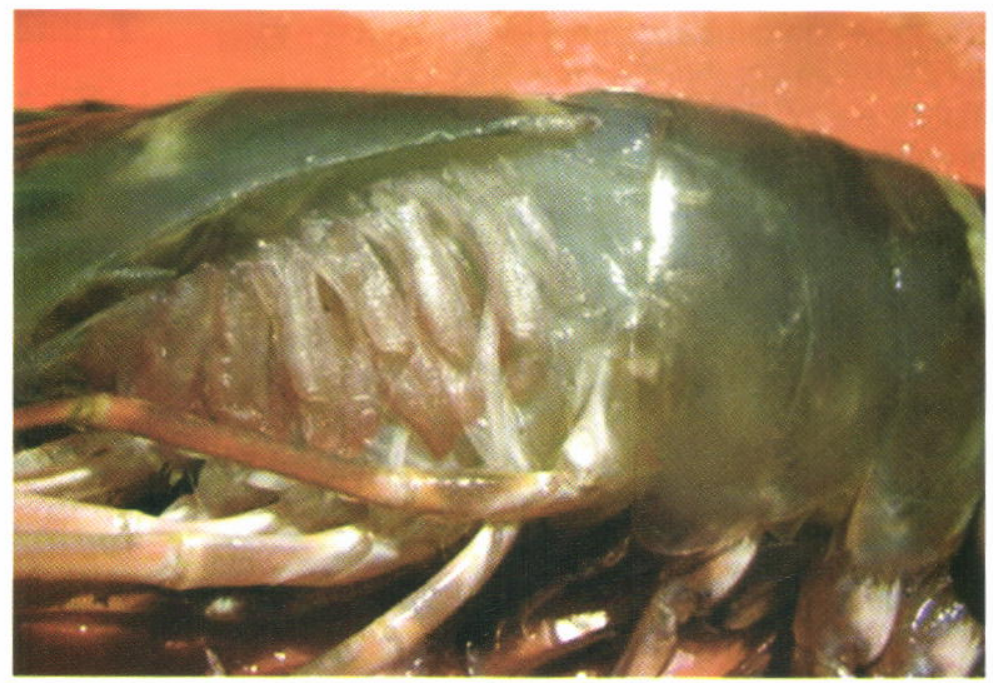

Gambar 3. Induk udang windu dari Jawa Timur dengan gejala klinis insang merah Figure 3. Penaeid shrimp collected fro East Java which indicated reddish gill

Hasil analisis dengan PCR dari sejumlah sampel (5 ekor) Pangandaran 1 tidak ditemukan adanya infeksi WSSV. Namun sampel lain dari Pangandaran 2 yang diterima dari Balai Budidaya Air Payau (BBAP), Jepara ternyata dari 11 ekor sampel, $81 \%$ (9 ekor) terinfeksi WSSV.

Perbedaan terjadi pada dua kelompok sampel yang berasal dari Pangandaran 1 dan Pangandaran 2 yang diambil pada waktu yang tidak sama. Pada sampel Pangandaran 1 dari 5 ekor sampel tidak ada yang menunjukkan infeks! WSSV, sedangkan dari sampel Pangandaran 2 sampel diketahui bahwa 9 dari 11 sampel ternyata terinfeksi WSSV. Perbedaan ini terjadi karena mungkin lokasi area penangkapan kedua kelompok sampel induk tersebut berbeda, atau mungkin karena pengaruh musim yaitu Pangandaran 2 diambil pada musim kemarau sedangkan pangandaran 1 diambil pada musim penghujan. $\mathrm{Hal}$ ini juga terjadi pada sampel Pangandaran 3 yang dikirim dari Ditjen Perikanan Budidaya pada bulan Agustus dimana dari 8 ekor induk udang windu tidak satupun yang menunjukkan adanya infeksi WSSV.

Hasil dari survai pada bulan-bulan berikutnya yang dilakukan di Jawa Tengah (Cilacap) dan Jawa Timur serta Bali juga menunjukkan bahwa dari sampel yang diperoleh tidak terdapat induk udang yang terinfeksi oleh WSSV. Namun sampel yang diterima dari NTB ternyata dari 11 ekor induk udang terdapat 6 ekor terinfeksi WSSV.

\section{KESIMPULAN}

Dari hasil penelitian in maka dapat diambil kesimpulan bahwa:

1. Induk udang windu ( $P$. monodon) hasil tangkapan dari alam tidak semua terinfeksi oleh WSSV. Ada tempat-tempat penangkapan induk udang windu yang masih bebas dari infeksi WSSV. 
2. Induk udang windu yang ditangkap pada bulan Juni-Oktober tidak menunjukkan adanya infeksi WSSV.

\section{UCAPAN TERMAKASIH}

Keberhasilan penelitian ini tidak lepas dari bantuan beberapa pihak. Oleh karena itu, pada kesempatan ini kami ingin mengucapkan terima kasih kepada Kepala Dinas yang membawahi perikanan di Provinsi Lampung, Banten, Jawa Barat, Jawa Tengah, dan Jawa Timur. Ibu Retno (BBAP) Jepara yang telah mau mengirimkan sampel yang berasal dari Pangandaran dan NTB. Bapak Mujahidin, PPS Kabupaten Pandeglang yang telah membantu dalam memperoleh sampel dari Panimbang. Hessy Novita, Desy Sugiani, Tuti Sumiati, Bambang Priyadi, Mikdarullah, dan Edi Farid di Laboratorium Kesehatan Ikan, Pasar Minggu atas kerja samanya yang tidak pernah mengenal lelah.

Semoga semua budi baik Bapak, lbu, dan Saudara semua mendapat balasan yang setimpal dari Allah SWT.

\section{DAFTAR PUSTAKA}

Graindorge, V.A. and T.W. Flegel. 1999. Diagnosis of Shrimp Diseases: with Emphasis on the Black Tiger Shrimp (Penaeus monodon). CD interactive. FAO and Multimedia Asia Co., Ltd., Bangkok, Thailand.

Goarant, C.L. Brizard, and A.L. Marteau. 2000. A white spot disease-like syndrome in the pasific blue shrimp (Lytopenaeus stylirostris) as a from of bacterial shell disease. Aquaculture, 18: 25--30.
Hosain, M.S., A. Chakraborty, B. Joseph, S.K. Otta, and I. Karunasagar. 2001. Detection of new hosts for white spot syndrome virus of shrimp using nested polymerase chain reaction. Aquaculture, 198: 1--11.

Koesharyani, I., D. Roza, K. Mahardika, F. Johnny, Zafran, and K. Yuasa. 2001. Manual for Fish Disease Diagnosis 11: Marine Fish and Crustacean Diseases. in Indonesia. In Sugama, K., K. Hatai, and T. Nakai (Eds.). Gondol Research institute for Mariculture. Central Research Institute for Sea Exploration and Fisheries and Japan International Cooperation Agency, 49 pp.

Lightner, D.V. editor. 1996. A Handbook of Shrimp Pathology and Diagnostic Procedure for Diseased of Culture Penaeid Shrimp. World Aquaculture Society, Louisiana, USA, $489 \mathrm{pp}$.

Surtida, M.B. 2000. A glimpse at shrimp culture in Indonesia. SEAFDEC Asian Aquaculture, XXII (6): 7pp.

Tang, K.F.J. and D.V. Lightner. 2000. Quactification of white spot syndrome virus DNA through a competitive polymerase chain reaction. Aquaculture, 189: 11-21.

Taslihan, A. R. Handayani, E. Maftuti Nur, dan Taukhid. 2004. Aplikasi teknik PCR (Polymerase Chain Reaction) dalam proses skrining induk udang windu dalam rangka mendapatkan benih bebas virus bercak putih (WSSV). Makalah Disampaikan pada Forum Seminar Aplikasi Biokimia dan Biologi Molekuler di UGM, 2 Oktober 2004, 15 pp.

Yuasa, K., Zafran, I. Koesharyani, D. Roza, and F. Johnny. 1998. Manual for PCR Procedure, Rapid Diagnosis for White Spot Syndrome of Shrimp. Multispecies Hatchery Project (ATA-379). Gondol Research Station for Coastal Fisheries-Japan International Cooperation Agency, 8 pp. 
